Weerahewa, Gunatilake, Thrikawala and Kotagama. 2000. Sri Lankan Journal of Agricultural Economics. Volume 3, Number 1.Pp 123 - 141.

\title{
Impact of Potato Trade Liberalisation on Soil Erosion: A Multi Period Market Simulation Model
}

\author{
J. Weerahewa*, H.M. Gunatilake*, \\ S. Thrikawala ${ }^{* *}$ and H.B. Kotagama
}

\begin{abstract}
This study quantifies the welfare changes in potato trade liberalisation in Sri Lanka incorporating long-term social cost of soil erosion into a multiperiod market simulation model. Seven alternative crops were considered for studying long-term land use changes induced by potato trade liberalisation. On-site cost of soil erosion was incorporated in the model through a dynamic soil depth crop yield function and cumulative off-site costs were deducted in calculating net welfare changes associated with land use changes induced by potato trade liberalisation. The results show that gain in consumer surplus is much higher than loss in producer surplus, government revenue and environmental cost. Thus, findings show that trade liberalisation is welfare improving. With regard to the impact of trade liberalisation on environment, the findings are however, non-conclusive. Depending on the empirical setting, trade liberalisation may induce environmentally friendly or unfriendly land use changes. Some environmental policies may be necessary in conjunction with trade liberalisation as it may not necessarily induce environmentally friendly land use changes.
\end{abstract}

\footnotetext{
$*$, **** Senior Lecturers, and Professor respectively, Faculty of Agriculture, University of Peradeniya. Research Officer, International Water Management Institute.
} 


\section{Introduction}

Economic theory asserts that there are gains from trade under most of the circumstances. With the acceptance of this basic trade theory, there is a drive for trade liberalisation globally. Among many interesting issues of trade liberalisation, environmental impacts occupy an important place. Trade liberalisation may lead to positive or negative environmental impacts. If the magnitude of the negative environmental impacts is very high, they may counteract the welfare gains from trade.

Empirical studies on the impact of trade on environment have provided mixed results. Some studies concluded that the impact of trade on environment is positive whereas others concluded that it is negative. Antle, (1993); Copeland and Taylor, (1995); Espinosa and Smith, (1995); Beghin et al., (1995) and Devarajan, (1995) provide a good discussion on the issues involved. Since the impact of trade on the environment has not been adequately understood, more empirical evidence on this subject will be useful in formulating both trade and environmental policies.

Against the above background, this study aims to assess the economic and environmental impacts of potato trade liberalisation in Sri
Lanka. Potato is cultivated in highland areas where soil erosion is a problem. Location of the cultivation in an economically important watershed elevates the importance of the environmental impacts of potato cultivation. Recently, the government reduced the tariff protection provided to potato farmers. This lead to reduction of potato cultivated area and a dramatic increase in potato imports. The welfare impacts of the potato trade liberalisation is still debated in the Sri Lankan society and there are various claims on the impact on environment. Most of the claims are however, without proper scientific investigations. Therefore, it is timely to quantify the welfare impacts of potato trade liberalisation so that the general public as well as the policy makers can be informed of scientific findings.

This study utilises the most recent estimates on on-site and offsite cost of soil erosion in a dynamic model to assess the long-term impact of potato trade liberalisation on the economy and the environment. Compared to the previous studies on assessing the impact of trade liberalisation on the economy and environment (Bandara and Coxhead, 1995; Bandara et al., 1997; Somaratne, 1997; Thrikawala and Kotagama, 1998 and Weerahewa et al., 1999), the present study includes 
a number of innovations. They are, assessment of impacts over 50-year period to capture the dynamics of productivity losses and off-site effects, internalisation of the on-site effect of soil erosion by incorporation of the dynamic impact of change in soil depth on crop yields, use of more accurate data on off-site effects that include all the possible off-site effects, and expansion of crop mixtures used in Weerahewa et al., (1999) to reflect possible long-term land use changes associated with trade liberalisation.

The paper is organised as follows. The second section presents a theoretical model. The third section presents an empirical model, data and assumptions. The fourth section presents the results. The paper ends with policy implications derived from the study.

\section{Theoretical Model}

This section presents a model, which analyses the impact of trade liberalisation on two horizontally related markets over the long run. Consider the equilibrium of two horizontally related markets (1 and 2 ) in figure 1. In market 1, supply schedule and demand schedule are shown by $S_{1}$ and $D_{1}$ respectively. Imports of the product in market 1 are restricted through tariff barrier and world market price $\left(\mathrm{Pw}_{1}\right)$ lies below the domestic price $\left(\mathrm{Pd}_{1}\right)$ by an amount equal to tariff. Similarly, supply schedule in market 2 is shown by $\mathrm{S}_{2}$ and demand schedule in market 2 is shown by $\mathrm{D}_{2} . \mathrm{Pd}_{2}$ shows the domestic price.

This model can be used as a simple framework to assess the impact of removal of trade barriers in one market on the equilibrium in both markets. Consider trade liberalisation in the market 1 with the removal of tariff. As a result of decrease in price, the domestic supply will decrease $\left(\mathrm{Qs}_{1}\right.$ to $\left.\mathrm{Qs}^{\prime}{ }_{1}\right)$, demand will increase $\left(\mathrm{Qd}_{1}\right.$ to $\left.\mathrm{Qd}_{1}{ }_{1}\right)$ and imports will increase. In market 1 producer surplus will decrease (by area $\left.\mathrm{Pd}_{1} \mathrm{BE}^{\prime} \mathrm{Pw}_{1}\right), \quad$ government revenue will be zero and there will be gains in consumer surplus (by area $\left.\mathrm{Pd}_{1} \mathrm{CF}^{\prime} \mathrm{Pw}_{1}\right)$. The gain in consumer surplus is greater than the loss in producer surplus and government revenue. Thus, due to efficiency gains, overall economic welfare will increase.

Removal of tariff in market 1 will have repercussions on the market 2 as well. Labour, land and other inputs released from the market 1 , which was under protection earlier, will be used by the market 2 . As a result, supply schedule in market 2 will shift to $\mathrm{S}_{2}$. The 
resulting quantity supplied will be $\mathrm{Qs}^{\prime}{ }_{2}$. In market 2 producer surplus increases (area HOIK), and consumer surplus remains the same.

In summary, shaded areas in market 1 show the traditional gains from trade in a given period of time. Welfare changes due to trade liberalisation are not only due to trade gains, but also due to changes in environmental conditions. The following section shows the changes in environmental conditions in the two markets.

Consider the inter-temporal production externalities in market 1 and 2. With the trade liberalisation in market 1, supply reduces and consequently, off-site cost of soil erosion will be reduced. However, off site cost of soil erosion due to production in market 2 will increase due to trade liberalisation in market 1 as supply increase in market 2 .

Soil erosion caused by cultivation at time $t$ will have an impact on the supply at year $t+1$. This inter-temporal aspect of soil erosion can be modelled as follows. Figure 2 shows the equilibrium of a market at year $t$ and year $t+1$. Supply curve at year $t+1, \mathrm{~S}_{\mathrm{t}+1}$, lies above the supply curve at year $t, \mathrm{~S}_{\mathrm{t}}$, due to soil erosion. Due to growth in population, demand for the product will increase at year $t+1$ and the demand curve at year $t+1, \mathrm{D}_{t+1}$, lies above the demand curve at year $t, \mathrm{D}_{\mathrm{t}}$.

Figure 1: $\quad$ Equilibrium in two horizontally related markets.
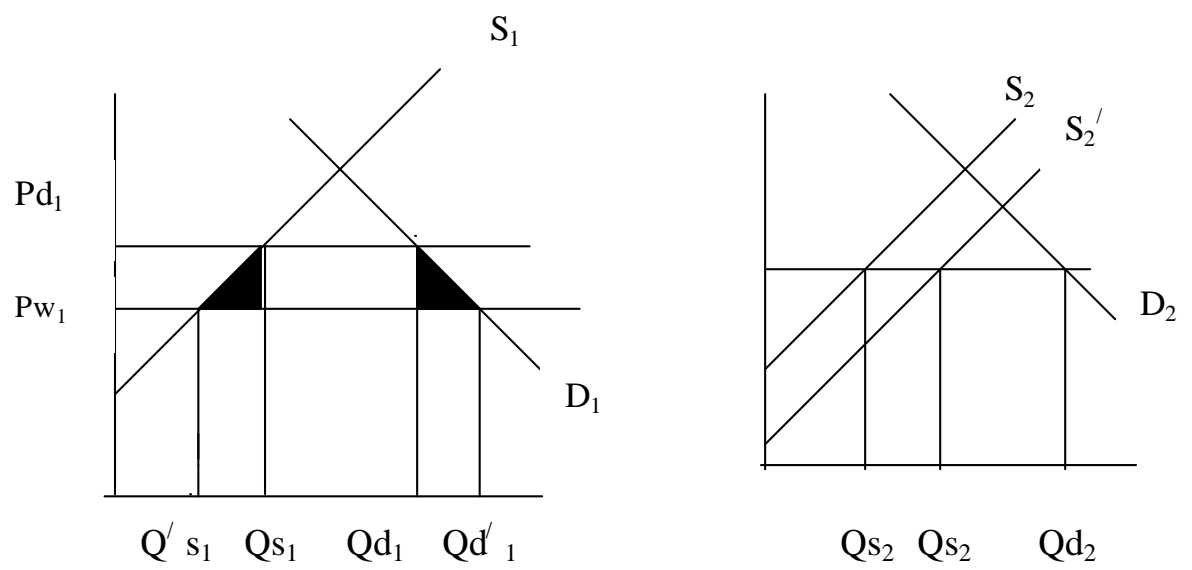
Figure 2: $\quad$ Equilibrium in a market with production externalities at two period of time.

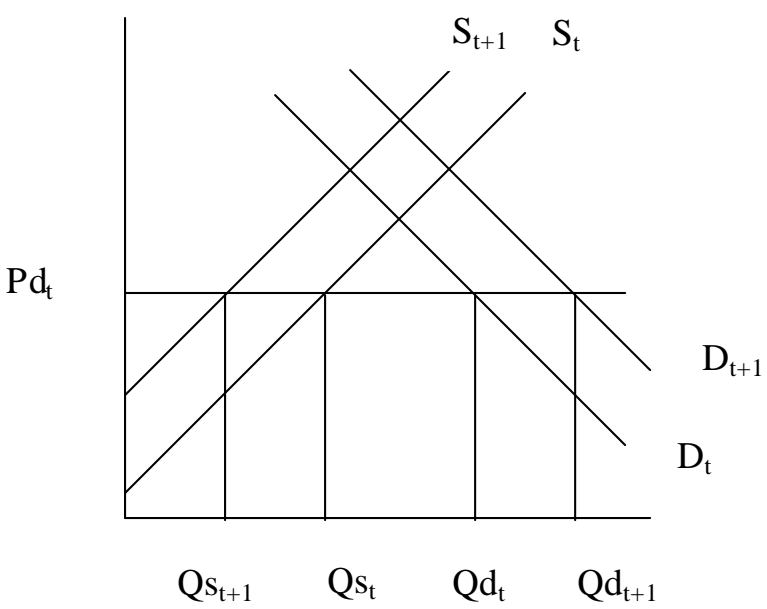

If world market price and tariff rate do not change, the quantity of domestic supply at year $t$ and $t+1$ are given by $\mathrm{Qs}_{\mathrm{t}}$ and $\mathrm{Qs}_{\mathrm{t}+1}$, respectively. Quantity of domestic demand at year $t$ and $t+l$ are given by $\mathrm{Qd}_{\mathrm{t}}$ and $\mathrm{Qd}_{\mathrm{t}+1}$ respectively, and the imports at the two periods are given by the difference between respective demand and supply. A number of supply curves and demand curves can be drawn in this manner for different years. Over the years, supply will decrease, demand will increase and imports will increase due to production externality. This process will continue until the vertical intercept of domestic supply curve is on or above $\mathrm{Pd}_{\mathrm{t}}$. When the intercept of domestic supply curve is the same as domestic price, domestic production will be zero and entire demand will be met by imports.

Figure 1 and figure 2 can now be combined to asses the impact of trade liberalisation in one market on two horizontally related markets over a long period of time in the presence of inter temporal production externality.

The sum of producer surplus, consumer surplus and government revenue shown in figure 1 could be discounted and added over years to find out economic gains and losses over the long run. The changes in the environmental cost can be measured as follows. Soil erosion caused by cultivation at time $t$ has off-site 
effects. Cost of the off-site effects are cumulative over years and total off-site cost can be obtained by summing discounted cumulative off site cost.

\section{Empirical Model, Data and Assumptions}

A simulation model based on the above theoretical model was used to find out the change in social welfare in potato and other markets before and after trade liberalisation of potato. Baseline equilibrium represents the markets before the trade liberalisation and counterfactual equilibrium represents the markets after trade liberalisation. The following section describes assumptions made in obtaining the baseline equilibrium of the potato market:

(i) A fifty-year planning horizon was considered.

(ii) Based on the field data, soil depth at period zero was considered as $16 \mathrm{~cm}$.

(iii) Current yield was considered as a function of soil depth of that year. Yield depth functions were used as follows to find out the yield every year.

Yld $_{t+1}=f\left(\mathrm{DPT}_{\mathrm{t}}\right)$

Where, Yld ${ }_{t+1}$ is the yield at year $t+1$ and DPT is the soil depth at the year $t$. (iv) Depth (DPT) reduces over years, according to erosivity of the crop. Soil loss values in tons/ha were used to find out the topsoil loss in $\mathrm{cm}$. It was assumed that soil erosion rates (Ero) are constants over time for a given crop.

$\mathrm{DPT}_{\mathrm{t}}=\mathrm{DPT}_{\mathrm{t}-1}$ - Ero

(v) Extent of land was considered as a constant. This is a very reasonable assumption as there is limited or no potential for further agricultural expansion in the upper Mahaweli watershed area.

(vi) Supply (S) was obtained by multiplying yield (Yld) by land extent (L) and cropping intensity (CI). Two crops per year were considered as the cropping intensity for annual crops.

$$
\mathrm{S}_{\mathrm{t}+1}=\text { Yld }_{\mathrm{t}+1 .} \mathrm{L}
$$

Notice that this formulation assumes that farmer internalises the on-site cost. The private internalisation of the productivity impact is perceived as follows. Farmer's this year cultivation results loss of some amount of topsoil. This loss lead to lower crop yields in the next year. $\mathrm{He}$ considers future loss of crop yields due to current soil 
erosion in maximising intertemporal profits. Therefore, the profit losses due to loss of topsoil are borne by the farmer himself.

(vii) Prices $\left(\mathrm{P}_{\mathrm{d}}\right)$ and cost of production (COP) were assumed to be constant over the planning horizon.

Returns on land is given by, Profit $=\mathrm{S}\left(\mathrm{P}_{\mathrm{d}}-\mathrm{COP}\right)$.

(viii) Off-site cost was obtained by multiplying per ha cost by the land extent. It increases in a cumulative way over the years. It was calculated assuming a sediment delivery ratio of $1 / 3$. It was weighted by the erosivity of crops, considering the offsite cost estimate (423 Rs/ha) for a crop with a erosion rate of 24 tons/ha.

(ix) It is assumed that demand grows at a rate of $1 \%$, which is the population growth rate.

(x) Imports are obtained by subtracting the local supply from the total quantity demanded.

(xi) Tariff revenue is obtained by multiplying imports by per unit tariff, which is equivalent to $35 \%$ of the price.

(xii) Consumer surplus is obtained by assuming that the demand is multiplicative $\left(\mathrm{D}=\alpha \mathrm{P}^{\beta}\right.$ where $\mathrm{D}$ is demand and $\mathrm{P}$ is price and $\alpha$ and $\beta$ parameters). Elasticity parameter was obtained by previous estimates. Shift parameter of this function was calibrated using the demand and price in the first period and the elasticity.

(xiii) All values are discounted using a $6 \%$ discount rate to obtain the present values. ${ }^{1}$ Sensitivity analysis was done with $4 \%$ and $8 \%$ discount rates.

(xiv) Sum of discounted profit, consumer surplus, tariff revenue net of off-site cost provides the social welfare over the 50 year period.

Trade liberalisation in the potato market reduces price by $35 \%$. Accordingly, demand and consumer surplus change. When prices drop by $35 \%$, potato producers get zero rents on potato land, since their cost of production is higher or same as the price of the imported potato. Hence potato producers will go out of business, and the total demand is met by the imports. No tariff revenue can be obtained since tariff level is zero. Since local production does not take

1. This is the recommended social rate of discount for Sri Lanka by the Ministry of Planning Implementation. 
place there is no environmental damage due to potato cultivation after removal of tariff.

In simulating the counterfactual equilibrium in the horizontally related market, it was considered that the production in market 2 increases as market 2 uses the land released from potato cultivation. The demand in market 2 does not change at a given period of time as a small open economy was assumed for market 2 . Vegetables, rice, tea, tobacco and timber were considered as the alternative markets for the resources used for potato.

To establish the relationship between productivity and soil depth for these crops, the following method was used. Different types of functional forms, such as linear, curvilinear, exponential, and Mistscherlich-Spillman (M-S) were generally used in the estimation of the relationship between productivity and soil depth. (Walker, 1982; Walker and Young, 1986; Segarra and Taylor, 1987; Van Kooten et. al., 1989; Gunatilake and Abeygunawardena, 1993). We assume in this study that M-S form accurately captures the relationship. The yield function takes crop yield as the dependent variable and topsoil depth as the explanatory variable. Algebraically the M-S function for yield and top soil depth is specified as follows:

$$
Y_{t}=a+b\left(1-R^{D_{t}}\right)
$$

Where

$$
\begin{aligned}
Y_{t}= & \text { is crop yield at time } t ; \\
a= & \text { is the per hectare crop } \\
& \text { yield theoretically } \\
& \text { obtainable from the } \\
& \text { subsoil when it is } \\
& \text { assumed that the topsoil } \\
& \text { is eroded; } \\
a+b= & \text { asymptotic value of the } \\
& \text { crop yield when lim. } Z_{t} \\
& \text { approaches infinity } \\
R= & \text { constant ratio of } \\
& \text { marginal product of } Z_{t+1} \\
& \text { topsoil depth to marginal } \\
& \text { product of } Z_{t} \text { topsoil } \\
& \text { depth. }
\end{aligned}
$$

The function has been developed with elicited data by a number of researchers. Segarra and Taylor (1987) used the M-S functional form to develop the relationship for tobacco, barley, wheat and corn in Virginia and they demonstrated that, for soybeans, elicitation produced results similar to plot-regression approach. Gunatilake and Abeygunawardena (1993) elicited the parameters of M-S function for tobacco, capsicum, and carrot in Hanguranketa Sri Lanka. Ananda et al., (1997) did the same for different types of tea. Since data based on erosion plot studies are not available, 
this analysis used the subjective elicitation procedure to find the parameters of M-S function for potato in the Welimada area of Sri Lanka. The yield functions are given in the appendix 1 .

Data on production, demand (which was obtained by adding production and imports), and prices were obtained from the publications of the Central Bank of Sri Lanka. Data on productivity was obtained from the Cost of Cultivation Reports published by the Department of Agriculture (see Appendix 2). Primary data required to estimate the relationship between productivity and soil depth were obtained from a sample survey. Erosion levels were gathered from research publications. These basic data are given in appendix 3 .

\section{Results and Discussion}

This section presents the results of different simulations that were carried out with different crops. Profit, consumer surplus, government revenue in the potato market and off-site costs due to potato cultivation were calculated before and after trade liberalisation. Results are presented in table 1. After trade liberalisation, no potato is grown, and hence the environmental damage due to potato cultivation is zero. Thus, potato trade liberalisation seems to be environmentally friendly. However, whether it is truly environmentally friendly depends on the emerging new land allocation due to potato trade liberalisation. If a less erosive crop such as VP tea uses the released lands from potato cultivation, potato trade liberalisation is environmentally friendly.

An important observation from table 1 is that the proportion of environmental cost as opposed to total economic benefits however was less than $1 \%$ even before trade liberalisation. This confirms the findings of the static model developed by Weerahewa et. al., (1999). A sensitivity analysis was conducted considering $4 \%$ and $8 \%$ as social discount rates and table 2 presents the major findings. The pattern of results remains the same with all discount rates used.

The column "net welfare" in tables 2 and 3 was obtained by deducting off-site cost from the profit. It shows the social profits and is used as an index to compare different markets considering potato market as the base.

The impacts on the other markets were calculated assuming the lands released were completely utilised by 
Table 1: $\quad$ Welfare measures* for potato trade liberalisation (Rs. Billion)

\begin{tabular}{lcc}
\hline \multicolumn{1}{c}{ Measure } & $\begin{array}{c}\text { Before trade } \\
\text { Liberalisation }\end{array}$ & $\begin{array}{c}\text { After trade } \\
\text { Liberalisation }\end{array}$ \\
\hline Profit & 38.84 & 0.00 \\
Consumer surplus & 229.86 & $25,758.37$ \\
Tariff revenue & 9.42 & 0.00 \\
Environmental cost & 0.53 & 0.00 \\
\hline Total & 277.61 & $25,758.37$ \\
\hline
\end{tabular}

* Analysis was carried out at 6\% discount Rate.

Table 2: $\quad$ Sensitivity analysis for the potato market (Rs. Billion)

\begin{tabular}{cccc}
\hline DR & Profit & Off-site & Net welfare \\
\hline $4 \%$ & 52.03 & 0.86 & 51.16 \\
$6 \%$ & 38.84 & 0.52 & 38.32 \\
$8 \%$ & 30.55 & 0.34 & 30.21 \\
\hline
\end{tabular}

$\mathrm{DR}=$ Discount Rate

Table 3: $\quad$ Summary results for alternative crops (Rs. Billion)

\begin{tabular}{lccc}
\hline \multicolumn{1}{r}{ Crop } & Profit & Off-site cost & Net Welfare \\
\hline Potato & 38.84 & 0.52 & 38.32 \\
Seedling & 29.50 & 0.78 & 28.72 \\
VPT & 39.75 & 0.17 & 39.60 \\
Eucalyptus & 0.69 & 0.081 & 0.60 \\
Carrot & 8.92 & 0.22 & 8.70 \\
Rice & 3.25 & 0.11 & 3.14 \\
Bean & 7.55 & 0.22 & 7.34 \\
Tobacco & 43.67 & 1.52 & 42.16 \\
\hline
\end{tabular}


the alternative crop. Table 3 presents the results. In the table, the potato row represents the before trade liberalisation welfare measures while other rows represent the welfare measures if all the lands which were under potato are allocated for the alternative crop. Net welfare due to tobacco is higher than that of potato with all discount rates leading to efficiency gains. However, there are adverse impacts on the environment as shown by the higher off-site cost values as compared to those of potato. As shown in the table 3 , net welfare due to carrot, bean, rice and eucalyptus ${ }^{2}$ cultivation is lower than that of potato cultivation with all discount rates. Eucalyptus was considered as the forestry alternative in this analysis in absence of the data for other forest crops. With fast growing high quality timber species the results may be different. Even though the impacts on the environment are beneficial with those crops, producers are worse-off. Therefore it is unlikely that farmers will allocate their land for these crops. Net welfare due to seedling tea cultivation is lower than that of potato cultivation with all discount rates. The environmental damage, however, is very much higher with the seedling tea than that of potato and producers are adversely affected. Therefore allocation of land, released from potato for seedling tea is economically as well as environmentally inefficient. Net welfare due to vegetatively propagated tea (VP tea) cultivation is higher than that of potato cultivation with all discount rates. The environmental damage however is lower with the VP tea than that of potato. There are gains to producers and environmental damage is minimum in the case of VP tea. Therefore, shifting from potato to VP tea can be considered as a win-win situation.

In summary, off-site cost associated with cultivation of the crops is very much lower than the conventional social welfare gains in the potato market. This is true for all the crops considered in this analysis. For example highest off-site cost is recorded for tobacco and it is equal to Rs. billion 1.52. The next highest is seedling tea, which is equal to Rs. billion 0.78 . With potato the off-site cost is Rs. billion 0.52 and with all other crops considered, the off-site cost is less than that. Figure 3 shows the changes in off-site costs of cultivation with different crops.

2. Net welfare due to Eucalyptus cultivation is lower than that of potato cultivation with all discount rates. Even though the impacts on the environment are beneficial, producers are worse-off. The net welfare is negative as increase in off site cost is greater than the profit. 
Figure 3: Discounted off-site cost of erosion caused by different crops over 50-year period.

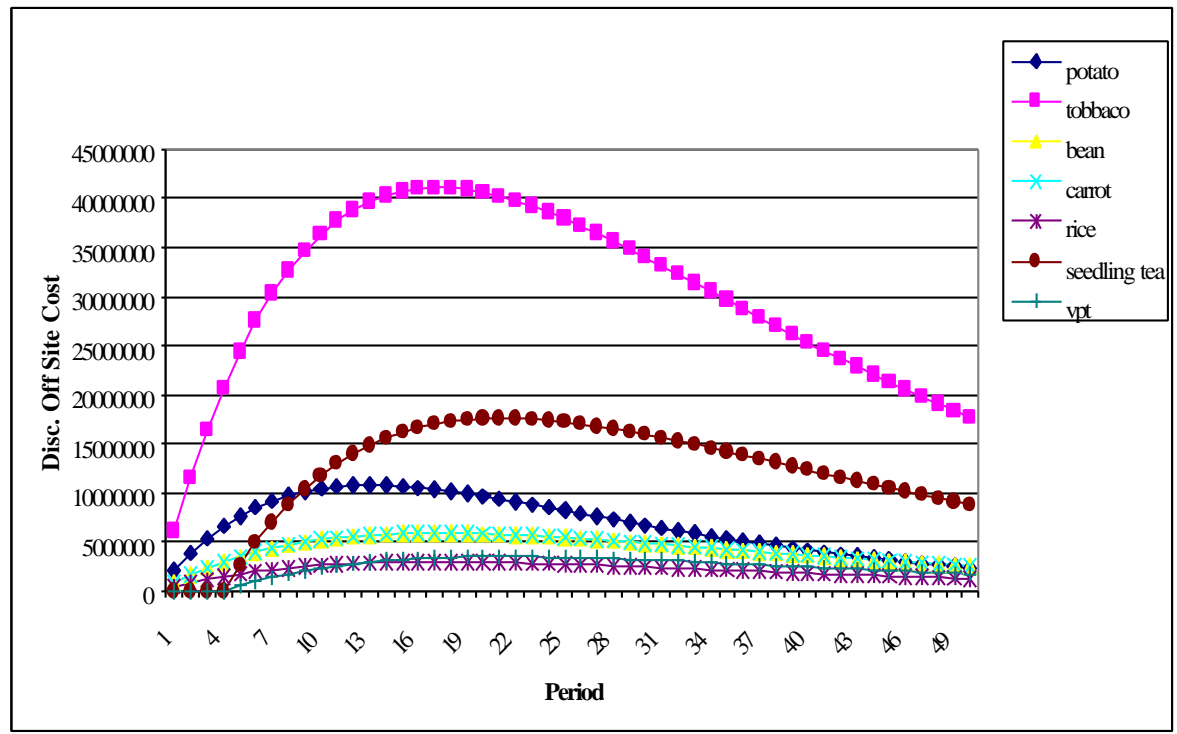

Figure 4: $\quad$ Profitability of different crops over 50 years.

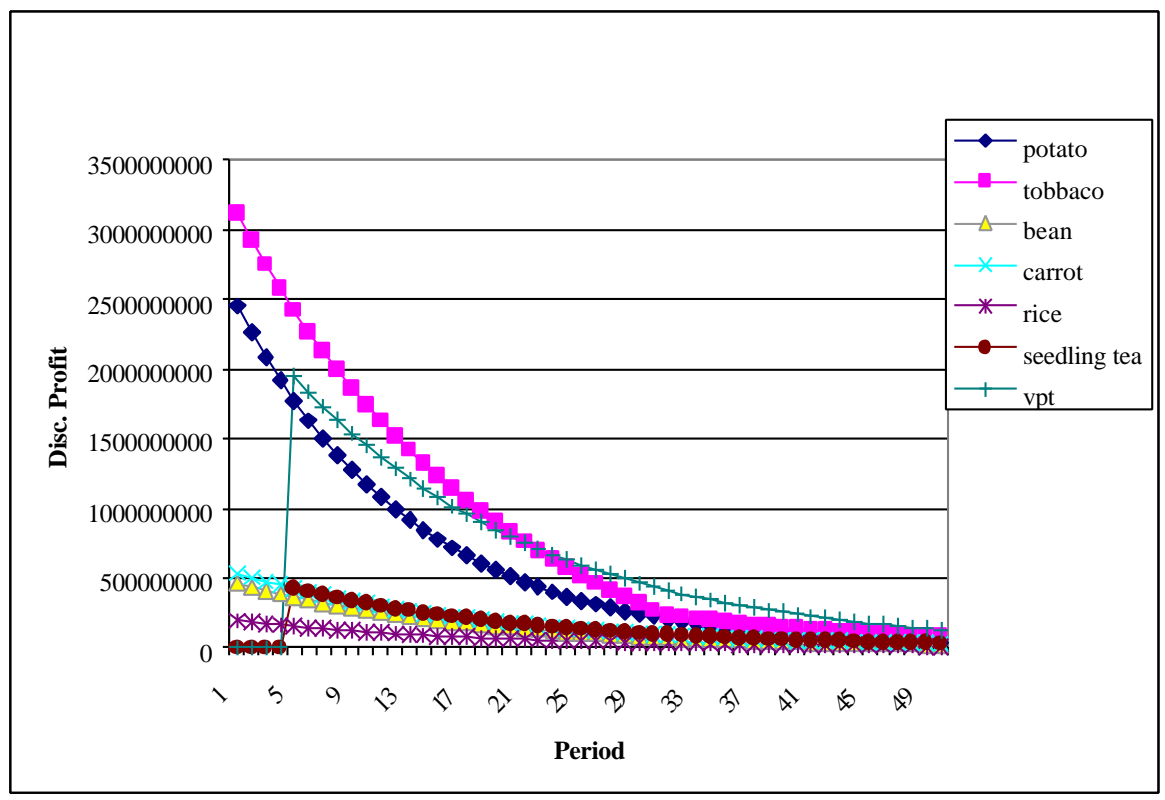


According to results at each time period, off-site cost is higher with tobacco and seedling tea than that of potato and other annual crops.

If potato lands are converted to less erosive and less profitable crops such as carrot, bean, rice or eucalyptus, benefits to producers and environmental damage will be reduced. If potato lands are converted to more erosive and less profitable crops such as seedling tea, benefits to producers will go down, and environmental damage will go up. If they are converted to more erosive highly profitable crops such as tobacco both benefits to producers and environmental damage will be increased (Table 4). If they are converted to less erosive, highly profitable crops such as VP tea producers gain, and environmental damage will be reduced. Summary of the findings is reproduced in table 4.

The long-term solution to soil erosion problem lies in favourable land use changes. If the market forces govern the land use changes, inter-temporal profit will be the governing force of that change. Figure 4 summarises the profit of each crop over 50-year period. The upper envelope predicts the land use pattern in the long run. It is based on the private profitability of the producers. According to results, VP tea and tobacco produce higher returns than that of potato. However, such a move has not taken place before the trade liberalisation of potato. There can be many reasons for not allocating the lands for most profitable crops. For example, tobacco cultivation is promoted by a multinational company and expansion of tobacco cultivation may be constrained due to institutional rigidities. Before potato trade liberalisation producers prefer to cultivate potato than VP tea, due to number of reasons. First is the time lag. Tea is a perennial crop and hence it may take a few years before its first harvest is taken. Second is the downside risk. The price fluctuation is higher with tea than with annual crops. Third is the institutional rigidity. In the upcountry, tea cultivation is mainly done by the plantations than small producers. Furthermore, physical land suitability may also be a factor that restricts land use changes that are induced by economic reasons. 
Table 4: $\quad$ Summary of results

\begin{tabular}{|c|c|c|c|c|}
\hline Crop & $\begin{array}{l}\text { Profitability } \\
\text { compared to } \\
\text { potato }\end{array}$ & $\begin{array}{l}\text { Erosion } \\
\text { compared to } \\
\text { potato }\end{array}$ & $\begin{array}{l}\text { Welfare of } \\
\text { producers }\end{array}$ & $\begin{array}{l}\text { Environmental } \\
\text { condition }\end{array}$ \\
\hline Tobacco & High & High & Win & Loose \\
\hline $\begin{array}{l}\text { Carrot, Bean, } \\
\text { Rice, } \\
\text { Eucalyptus }\end{array}$ & Low & Low & Loose & Win \\
\hline Seedling tea & Low & High & Loose & Loose \\
\hline VP tea & High & Low & Win & Win \\
\hline
\end{tabular}

\section{Conclusion and Policy Implications}

This study quantifies the welfare changes associated with liberalisation of potato market in Sri Lanka. Recognising the major weakness of this type of analysis in the past, this study quantifies the long-term social cost of soil erosion into welfare analysis of trade liberalisation. The results show that the gain in consumer surplus is higher than the loss in producer surplus, government revenue and the environmental cost for all the crops considered. There is an overall gain in social welfare due to potato trade liberalisation. Our analysis, thus provides further empirical evidence for the theoretical assertion that trade liberalisation is welfare improving. Policy makers could consider potato trade liberalisation as efficiency improving when trade policies are designed.

Any economic policy is associated with gainers and losers. As clearly evident from our analysis, potato consumers gain enormous benefits due to trade liberalisation. However, there could be adverse impacts on the producers if potato lands are used for vegetables, forests or seedling tea. The environmental cost will increase if potato lands are used for tobacco or seedling tea. With VP tea welfare of the producers and environmental conditions will be improved. When gains outweigh the losses, as in the case of potato trade liberalisation, the policy is acceptable on efficiency grounds. However, additional policy measures may be necessary to ameliorate the adverse impacts faced by potato producers. 
The findings are inconclusive with regard to the impact of trade liberalisation on the environment. As shown by the predicted land use changes, if land use changes are governed by economic concerns, released potato lands should be allocated for tobacco or VP tea. Tobacco is a highly erosive crop while VP tea is an environmentally friendly crop in terms of soil erosion. Therefore trade liberalisation may lead to positive or negative environmental impacts depending on the empirical setting. Farmers' shifting from one crop to another will depend on many factors other than inter-temporal profits. Some environmental policies may be necessary in order to enhance the environmentally friendly land use changes in conjunction with trade liberalisation, as it may not necessarily induce environmentally friendly land use changes.

\section{Acknowledgement}

Authors acknowledge the financial support provided by the Economy and Environmental Program for the South East Asia (EEPSEA) and research support provided by Prof. J. Whally, University of Western Ontario.

\section{References}

Antle, J.M. (1993). Environment, Development, and Trade between High - and Low Income Countries. American Journal of Agricultural Economics, 75: 784-788.

Ananda, J., G. Herath and A. Chisholm (1997). A Soil Erosion Damage Function for Small holder Tea in Sri Lanka: An Empirical Estimation. Paper Presented at the Workshop on Land Degradation and Policy Options in Sri Lanka.

Bandara, J.S. and I. Coxhead (1995). Economic Reforms and the Environment in Sri Lanka. Discussion Paper. School of Agriculture Bundoora, Victoria, Australia.

Bandara, J.S., A. Chisholm, A. Ekanayake and S. Jayasuriya (1997). On-site and Off-site Effects of Land Degradation in Sri Lanka: Tax/Subsidy Policy Options. Unpublished Manuscript. 
Beghin, J., D. Roland-Holst and D. van der Mensbrugghe (1995). Trade Liberalization and the Environment in the Pacific Basin: Coordinated Approaches to Mexican Trade and Environment Policy. American Journal of Agricultural Economics, 77: 778-785.

Copeland B.R. and S. Taylor (1995). Trade and the Environment: A Partial Synthesis. American Journal of Agricultural Economics, 77: 765-771.

Devarajan, S. (1995). Environment and Trade in General Equilibrium: Theory, Methodology, and Evidence: Discussion, American Journal of Agricultural Economics, 77: 786-788.

Espinosa, J.A. and V.K. Smith (1995). Measuring the Environmental Consequences of Trade Policy: A Nonmarket CGE Analysis. American Journal of Agricultural Economics, 77: 772-777.
Gunatilake H.M and P. Abeygunawardene (1993). Farm Level Economic Analysis of Soil Erosion Control in Tobacco Lands in the Hanguranketha Area. Tropical Agricultural Research, 5: 129-141.

Segara, E. and D.B. Taylor (1987). Farm Level Dynamic Analysis of Soil Conservation: An Application to the Piedmont Area of Virginia. Southern Journal of Agricultural Economics, 19(2): 61-73.

Somaratne, W.G. (1997). Policy Liberalisation and the Environment in Sri Lanka: A Computable General Equilibrium Analysis. Paper Presented at the Workshop on Land Degradation and Policy Options in Sri Lanka held in 1997.

Thrikawala, S. and H.B. Kotagama (1998). Impact of Selected Macro Economic Policies on Soil Erosion in Sri Lanka. Tropical Agriculture Research. 10: 179-191. 
Walker, D.J. (1982). Damage Weerahewa, J., H. Kotagama and Function to Evaluate S. Thrikawala (1999). Erosion Control Economics. Impacts of Trade on American Journal of Environment: Potato Trade Agricultural Economics, Liberalisation and Soil 64(3): 690-698.

Walker, D.J. and D.L. Young Erosion in Sri Lanka. Final Report Submitted to (1986). The Effect of Technical Progress on Erosion Damage and Economic Incentives for Soil Conservation. Land Economics, 62(1): 83-93. Economy and Environment Program for South East Asia.

Van Kooten, G.C. (1993). Land Resources Economics and Sustainable Development. Vancouver: University of British Colombia Press. 
Appendix 1: $\quad$ Soil depth and productivity relationship for Sri Lanka.

\begin{tabular}{lll}
\hline Crop & Function & Reference \\
\hline $\begin{array}{l}\text { Tobacco. } \\
\text { Capsicum. }\end{array}$ & $\mathrm{Y}=3309.7+4682.7\left(1-0.85^{\mathrm{D}}\right)$ & Gunatilake and Abeygunawardena (1993) \\
& $\mathrm{Y}=1213.1+3320.2\left(1-0.86^{\mathrm{D}}\right)$ & Gunatilake and Abeygunawardena (1993) \\
Carrot. & $\mathrm{Y}=1339.2+4551.4\left(1-0.79^{\mathrm{D}}\right)$ & Gunatilake and Abeygunawardena (1993) \\
& & \\
High Grown Tea & $\mathrm{Y}=3497+9040\left(1-0.85^{\mathrm{D}}\right)$ & Ananda et al. (1998) \\
& & \\
Mid Grown Tea & $\mathrm{Y}=1551+4166\left(1-0.85^{\mathrm{D}}\right)$ & Ananda et al. (1998) \\
Low Grown Tea & $\mathrm{Y}=3919+10015\left(1-0.85^{\mathrm{D}}\right)$ & Ananda et al. (1998) \\
Potato & $\mathrm{Y}=6364.81+18555.55$ & This study \\
& $\left(1-0.97^{\mathrm{D}}\right)$ & \\
Bean & $\mathrm{Y}=6355+10976\left(1-0.97^{\mathrm{D}}\right)$ & This study \\
\hline
\end{tabular}

Appendix 2: Base values and parameters used in the study.

\begin{tabular}{llll}
\hline Crop & $\begin{array}{l}\text { Price } \\
\text { Rs./kg }\end{array}$ & $\begin{array}{l}\text { Cost of Production } \\
\text { Rs./kg }\end{array}$ & Source \\
\hline Potato & 30 & 29 & \\
Tobacco & 96 & 70 & Department of Agriculture* \\
Bean & 10.5 & 7.6 & Department of Agriculture \\
Carrot & 12 & 9 & Department of Agriculture \\
Rice & 9.66 & 6.91 & Department of Agriculture \\
Tea & 134 & 106 & Central Bank** \\
$* * *$ & Cost of Cultivation reports. & Central Bank \\
Annual Reports, various years. &
\end{tabular}


Appendix 3: $\quad$ Soil loss estimates.

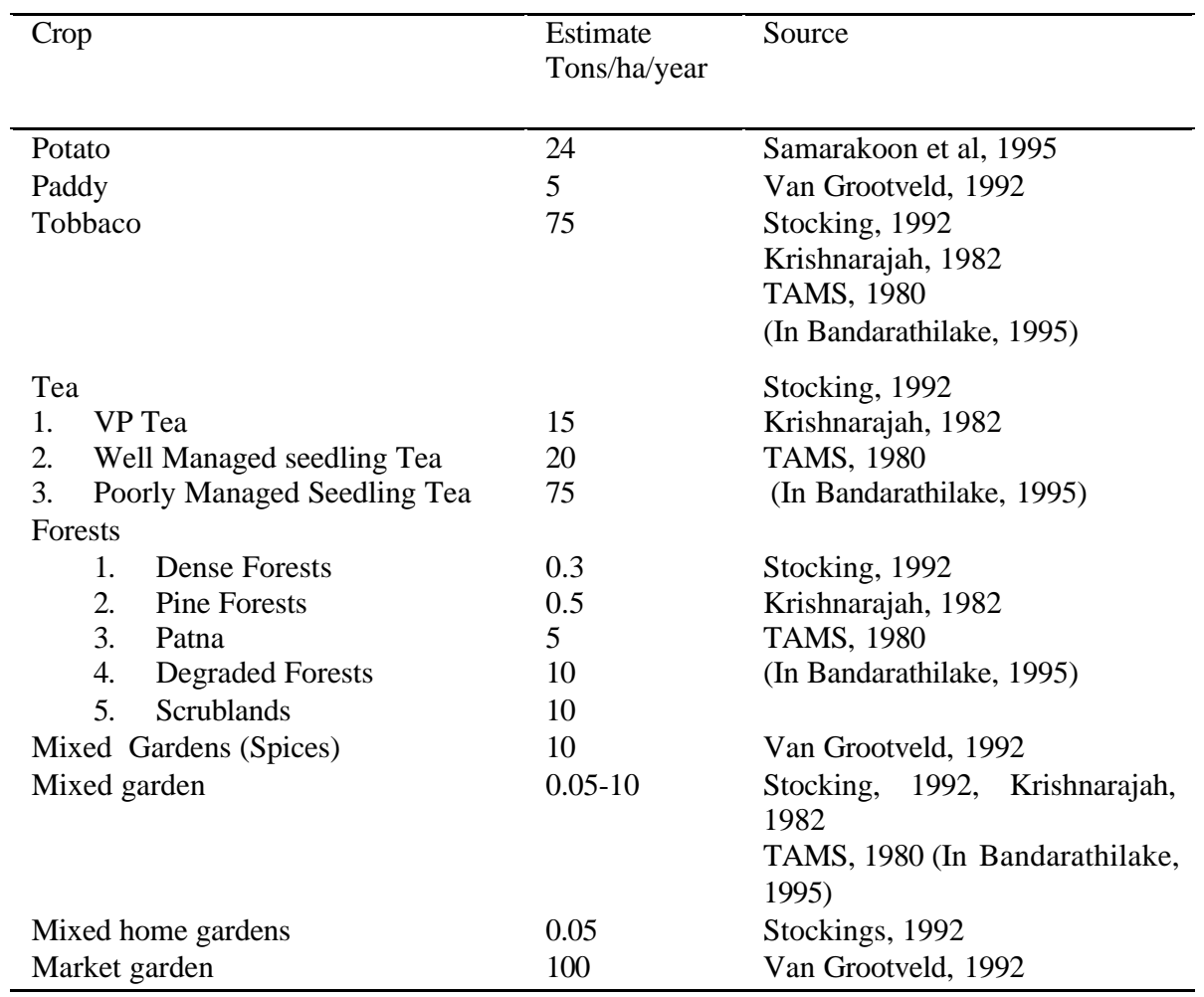

